\title{
Alternative off school Business Models that Enhance Multiple Intelligences in Kenyan Schools
}

\author{
David Maboko Nassiuma \\ Jonah N. Kindiki (Proffesor) \\ Sammy K. Chumba (Dr) \\ Department of Educational Management and Policy Studies, \\ Moi University, Kenya
}

doi: 10.19044/esj.2017.v13n22p306 URL:http://dx.doi.org/10.19044/esj.2017.v13n22p306

\begin{abstract}
Promotion of individual development and self-fulfillment amongst students in Kenya is among the national goals of education. To accomplish this goal it is imperative that, development of Multiple Intelligences in schools is put into perspective. To date, relatively little research has investigated the ways students Multiple Intelligences should be enhanced in Kenya. Consequently, this study was devised to examine alternative off school business management models that enhance Multiple Intelligences among secondary students in Kenya. The study was guided by the Multiple Intelligence Theory and Management Competency Framework. The study target population was 150 secondary schools in Elgeyo Marakwet. Data was collected using questionnaire, document analysis and interview. The data was analyzed qualitatively using thematic approach and quantitatively using percentages, means, standard deviation and simple linear regression. Data was presented in tables. The findings indicated that schools management was managing traditional models of enhancing multiple intelligences thus majority of the students' abilities were not developed. Alternative off school business management models were found to be effective in enhancing multiple intelligences among students though majority of the schools had not adopted them. The study recommends that managing and facilitating entrepreneurship programmes should be promoted to enable students to show case abilities in different intelligences.
\end{abstract}

Keywords: Models, Multiple Intelligences, Secondary students

\subsection{Introduction}

As a developing nation in the $21^{\text {st }}$ century, Kenya and its government are facing numerous challenges that are obstacles in the path of transforming 
into a fully developed country (United Nations Development Programme, 2012). Therefore, this calls for the government and the nation to find long term and permanent solutions which are not easy. Conceivably, education can play a major role in this regard. It is in this view that, Boit, Njoki and Chang'ach (2012) asserted that education plays an important role in fashioning and modeling man to be able to function well in his environment.

However, questions that beg for answers are; is our education system effective or capable enough to address these problems? Are we producing whole rounded people who can transform this country into a modern economy? These questions can be dealt with when we delve into the alternative off school business management models that are being used in our secondary schools to develop multiple intelligences. This comes at a backdrop of many schools which are not modeled to give students an education that takes their individual needs into account.

The current research took as its starting point the gist of multiple intelligences (MI) as provided by the MI theory that each person possesses eight intelligences, and uses them to carry several kinds of tasks (Gardner, 2006; Boonma \& Phaiboonnugulkij, 2014). These include; interpersonal intelligence that allows one to understand and work with others. Intrapersonal intelligence that encompasses people who would rather work alone than be forced to work in a group, and are often labeled shy. Linguistic/Verbal intelligence that has everything to do with language, speech, reading, and writing. Spatial intelligence defined as the capacity to perceive the visual world accurately through transforming, modifying and recreating the aspects of one's individual real world (ibid). Logical/Mathematical intelligence that involves manipulation of objects and problem solving. Musical intelligence involving the ability to understand pitch, rhythm, and tone as well as thinking in sound. Bodily/Kinesthetic intelligence being the ability to think in movement (ibid). Naturalist intelligence that is displayed in a person who is intelligently aware of how to distinguish the diverse plants, animals, and the physical environment in their ecological niche (ibid).

It is from this premise that school management should endeavor to create an environment that aims to enhance these intelligences that are amid our students by coordinating alternative off school business management models. Alternative off school business management models are defined in this research as complimentary/ innovative practices in which the school management directs, facilitates, coordinates students' participation in substitute activities out of class that includes entrepreneurship and networking with agencies/ stakeholders.

It is important to note that students' development is essentially influenced by school-family-community partnerships. Castro et al. (2015) asserted that the importance of parents, schools and community interactions 
cannot be ignored in the affairs of the education of learners. Based on the needs of the community and the environment, the school should therefore decide on the suitable curriculum to modify the existing curriculum to suit the needs of the society. Phonkhao and Ounjit (2012) points that, schools, families' and the greater society are key social institutions in the development of children and youths. Emerson, Fear. Fox, and Sanders (2012) further suggests that, there is raised attainment, increased pupil engagement with learning and growing trust and support between families and schools in what this study describes as the off school business. Sulim (2012) concluded that students can collaborate with other schools or agencies outside school to provide greater flexibility and adaptability in the provision offered to pupils.

An earlier study by Webb \& Vulliamy (2004) funded by the Home Office in America, demonstrated improved attendance and a reduction in exclusions, when social workers were introduced in a small number of schools and when students participate as social workers. These studies, along with other reviews of extended schools (off school businesses), suggest that it might be possible to link initiatives in developing services beyond the classroom (Wilkin et. al, 2003). Back here in Kenya the Leap Hubs Initiative popularized by Stephen Njoroge who was Principal Moi Forces Academy and currently the director of Centre for Mathematics, Science and Technology Education in Africa (CEMATEA) exposes students to entrepreneurship life skills without undue emphasis on academic scores (Ombour, 2014).

Literature review has demonstrated that, it is the nature of the collaboration involved that seems to determine whether school collaboration with parents, has a positive impact on learning and longer term engagement with learning.

\subsection{Statement of the Problem}

Despite education institutions being a focal focus in the development of various intelligences among students thereby promoting individual development and self fulfillment (Gardner, 2006; Republic of Kenya, 2009) management models in schools managements have continued to apply a one size - fits - all model in attaining this goal (Gardner, 2006; McEvoy, 2013). Growing evidence suggest that many students don't thrive well in this traditional management model, thus a need for alternative off school business management models. Alternative off school businesses (Deschenes et al., 2010) have been successfully used in developed countries to assist learners achieve their full potential in class and out of class activities thereby enhancing their multiple intelligences. Although Kenya has had notable initiatives in encouraging this development as seen in the usage of alternative model like the Leap Hubs Initiatives (Ombour, 2014) substantive challenges in education likely attributed to the existing traditional management models that 
emphasizes on academic content has been witnessed. The study therefore sought to examine alternative off school business management models for Multiple Intelligences among learners in secondary schools in Kenya.

\subsection{Objectives of the Study}

i. To examine the existing off school business management models that enhances Multiple Intelligences.

ii. To examine the alternative off school business management model that enhances multiple intelligences among students in Kenya.

iii. To determine whether alternative off school business management model that enhances multiple intelligences among students in Kenya.

\subsection{Hypothesis of the Study}

Ho: There is no statistically significant relationship between the alternative off school business management model and enhancement of multiple intelligences among students in Kenya.

\subsection{Research Methodology and Methods}

Research design is the plan that is employed by a researcher that specifies the sources and types of information relevant to the research problem (Briggs, Coleman and Morrison, 2012). There are three major frameworks for designing any study; quantitative, qualitative and mixed methods approaches. The three research approaches structure procedures and techniques differently (Creswell, 2013) and their philosophical underpinning have a wide-ranging research strategies and methods that can be implemented in particularly different ways.

A mixed methods design involves the collection and analysis of both quantitative and qualitative data in a single study in which data are collected concurrently or sequentially, are given priority, and involve integration of the data at one or more stages in the process of research (Onwuegbuzie \& Collins, 2007). This study adopted a mixed method concurrent approach where both quantitative and qualitative data was collected at the same time and using the same respondents. Johnson (2014) noted that in concurrently collecting both forms of data at the same time, the researcher gets to contrast both varieties of data to search for compatible outcomes. One compares the themes pinpointed in the qualitative data with the statistical results in the quantitative analysis.

Self administered fixed response questionnaire was used to get information from 108 Principals. A 7 point rating scale (1= extremely ineffective and $7=$ extremely effective) was used to measure the effectiveness of alternative off school business management models that enhance multiple intelligence. The questionnaire also sought to establish how the eight intelligences have been enhanced by school management through the 
alternative off school business model by using a 7 point rating scale $(1=$ actively and $7=$ passively). Reliability was calculated using split half method that was subjected to a Cronbach alpha test. A correlation coefficient (r) of .972 was obtained. The instrument was therefore reliable according to Cohen, Manion \& Morrison (2013) who states that a correlation coefficient of greater than 0.8 will be acceptable. The questionnaire was designed and developed in terms of content and construct validity. Content validity which refers to an assessment of whether items and questions cover the full range of the issues and investigation (Cohen et al., 2013) was done by the researcher in consultations with the experts in the Department of Educational Management and Policy Studies at Moi University who did a critique and put inputs. Researchers establish construct validity by relating a measuring to a general theoretical framework in order to determine whether the instrument is tied to concepts and theoretical assumptions they are employing (McCall, Jiao \& Harris, 2013). Again this was established by the assistance of the supervisors and experts in the Department of Educational Management and Policy Studies at Moi University.

As part of the criteria in selecting the qualitative instrument the researcher examined the foundations of the existing literature so as to make note of what is known about the topic and which approaches have been used in prior studies. A qualitatively skilled collaborator from the management and policy studies department was sought. Input from the qualitative expert ensured that rigor is employed from the study's inception. The grounded theory approach was then considered to enable answering of research question.

Semi structured interview was used in a face to face interview of 50 Board of Management chairpersons. The script was designed to formulate the broad overall questions that the study intended to answer. Translating the broad overall questions into measurable elements as precise questions was then considered. Such included a description of the existing off school business management models. The script then proceeded to the development of a pool of specific questions designed to elicit the desired information. Attention was on open ended questions that were likely to yield information about the study phenomenon and be able to address the aims and objectives of the research. The script was designed to start with questions that participants can answer easily and then proceed to more difficult or sensitive topics. This was aimed at putting respondents at ease, building confidence and rapport. Piloting was done in the neighboring Baringo County. Respondents were informed about the study details and given assurance about anonymity and confidentiality. The interviewer familiarized himself on the interview schedule, to enable the process to be more natural. Where appropriate, 
clarification from respondents was sought. The researcher thanked participants for their time.

\subsection{Findings and Discussion}

The first objective sought to examine the existing off school business management models that enhances Multiple Intelligences. The findings are presented below.

\subsection{Existing Off School Business Management Models for MI Development}

Document analysis guide indicated that learning activities in class and out of class did not enhance MI. The permission record book indicated that students left school purposively to go collect fees balances from home, suspensions, medical checkups and breaking of half term and holidays. Activities aimed at developing varied skills were either lacking or minimal. The school $\log$ at the gate showed little effect of acquisition of skills that may enhance MI activities. It is important to mention though, that, a few schools 4 out of 87 did invite comedians and Coca Cola promotional troupe commonly referred to as the Coke Light Studio. This enabled students to participate in song and poetry that enhanced their writing and musical skills.

The visitors' book commonly kept at the Principals office indicated that majority of the visitors were fellow Principals making courteous calls, Members of Parliament coming to greet students and old students coming to pick certificates. Such activities didn't impact on acquiring skills that can enhance students MI. Schools routine showed little effect to any learning activities that were related to MI development. Schools routines were the usual traditional routines that had the usual waking up, cleaning, lessons, breakfast, lunch, games supper, preps, church service, and lights off. Students who were endowed with interpersonal and spatial abilities were therefore not getting the necessary platform to sharpen those skills.

Interview responses from Board of Management (BoM) indicated that as much as there were alternative models for enhancing MI the traditional models did take lot of credence in schools. They said thus;

"Most of the activities that were carried out in schools (that is the off school business) were geared towards academic excellence and probably issues related to students social wellbeing that had a limited link to enhancement of MI. We do entrust parents during holidays to ensure that students benefit from activities carried out at their homes such as farming, business and fishing. It's important to mention that the school though put emphasis on the extra curricula activities such as games, sports and music." 
Further responses from the interview indicated that activities aimed to generate income for the school (income generating activities) were mostly run by teachers, support staff and contracted personnel. These include activities such as school canteen, milk and meat supply. This implies that many students may not be exposed to entrepreneurship skills. One BoM said;

"We rarely give tenders to students in relation to supply of goods and services. It is in the interests of the school that students concentrate in books and passing of exams. Such activities are not graded thus not very critical for academic progression of the students."

This implies that off school activities meant to enhance students MI were rarely coordinated, supervised nor directed by the BoM, Principals and HoDs.

\subsection{Alternative off School Business Management Models for MI development}

In view of the challenges anticipated by the existing off School Business Management models of enhancing MI the researcher sought to examine alternative off School Business Management models for enhancing MI among students. The findings are represented in Table 1 
Table 1: Alternative off School Business Management Models for MI development

\begin{tabular}{|c|c|c|c|c|c|c|c|c|c|c|}
\hline & \multirow{3}{*}{ Models } & \multicolumn{9}{|c|}{ Extent of Enhancing students Multiple Intelligences } \\
\hline & & 1 & 2 & 3 & 4 & 5 & 6 & 7 & Mean & Standard \\
\hline & & $\mathbf{F}(\%)$ & F $(\%)$ & $\mathbf{F}(\%)$ & $\begin{array}{c}\mathbf{F} \\
(\%)\end{array}$ & F $(\%)$ & $\mathbf{F}(\%)$ & $\mathbf{F}(\%)$ & & deviation \\
\hline A & $\begin{array}{l}\text { Working relations with other } \\
\text { education institution }\end{array}$ & $11(12.6)$ & 11(12.6) & $7(8.0)$ & $4(4.6)$ & $14(16.1)$ & 26(29.9) & $14(16.1)$ & 4.5287 & 2.07330 \\
\hline B & $\begin{array}{l}\text { Links with other countries (exchange } \\
\text { programmes) }\end{array}$ & $7(8.0)$ & $22(25.3)$ & 13(14.9) & $5(5.7)$ & $12(13.8)$ & $18(20.7)$ & $10(11.5)$ & 4.0000 & 1.98248 \\
\hline $\mathrm{C}$ & $\begin{array}{l}\text { Links with } \\
\text { local/regional/international } \\
\text { businesses }\end{array}$ & $8(9.2)$ & $21(24.1)$ & $15(17.2)$ & $6(6.9)$ & $20(23.0)$ & $12(13.8)$ & $5(5.7)$ & 3.7471 & 1.79934 \\
\hline D & $\begin{array}{l}\text { Links with corporate such as } \\
\text { safaricom, Yu, coca cola }\end{array}$ & $3(3.4)$ & $10(11.5)$ & $15(17.5)$ & $1(1.1)$ & $17(19.5)$ & $23(26.4)$ & $18(20.7)$ & 4.8391 & 1.84185 \\
\hline $\mathrm{E}$ & $\begin{array}{l}\text { Links with agencies such as Red } \\
\text { cross, Kenya Wildlife Service } \\
\text { (KWS) }\end{array}$ & $14(16.1)$ & $14(16.1)$ & - & $6(6.9)$ & $24(27.6)$ & 13(14.9) & $16(18.4)$ & 4.3218 & 2.13767 \\
\hline $\mathrm{F}$ & $\begin{array}{l}\text { Students representation to boards of } \\
\text { schools, churches, and corporate }\end{array}$ & - & $19(21.8)$ & $8(9.2)$ & $4(4.6)$ & $22(25.3)$ & $16(18.4)$ & $18(20.7)$ & 4.7126 & 1.82940 \\
\hline G & $\begin{array}{l}\text { Entrepreneurship programmes for } \\
\text { students }\end{array}$ & - & $12(13.8)$ & $16(18.4)$ & $8(9.2)$ & $19(21.8)$ & 11(12.6) & $21(24.1)$ & 4.7356 & 1.76832 \\
\hline & Job attachments and internship & $16(18.4)$ & $12(13.8)$ & $22(25.3)$ & $7(8.0)$ & $9(10.3)$ & $13(14.9)$ & $8(9.2)$ & 3.5977 & 1.96753 \\
\hline $\mathrm{H}$ & Vocational work & $14(16.1)$ & $6(6.9)$ & $7(8.0)$ & $6(6.9)$ & $23(26.4)$ & $12(13.8)$ & $19(21.8)$ & 4.4943 & 2.09581 \\
\hline
\end{tabular}


As indicated in Table 1 Principals in the sampled centers gave varying responses on the effectiveness of the various models. Concerning a directed, coordinated, and facilitated working relation with other educational institutions 14 (16\%) Principals in 87 sampled centers indicated that it may be extremely effective, 26 Principals (29.9\%) indicated quite effective and 14 (16.1\%) Principals in 87 centers indicated that it may be slightly effective. On the other hand $11(12.6 \%)$ Principals in 87 sampled centers indicated that a directed, coordinated, and facilitated working relation with other educational institutions may be extremely ineffective, 11(12.6\%) Principals indicated quite ineffective and $7(8.0 \%)$ principals in 87 sampled centers indicated that it may be slightly ineffective. As the results indicate such working relations with other institutions might enhance students' interpersonal intelligences whereby students will be given an opportunity to work and communicate with others. In so doing they will acquire communication skills which are essential in learning in the learning process. These findings are in line with Sulim (2012) who advocates that, "someone's intelligence can lead to the development of someone else's intelligence" (p. 1270). To be effective, collaboration needs resources, leadership, shared direction, ownership and responsibility. Sebba (2007) further pointed out that community links are normally enhanced when schools are closer to towns. This creates the potential for greater curricular flexibility (through shared provision), work experience and improved access for outreach work.

Further findings in Table 1 revealed that 7 (8.0\%) Principals in 87 sampled centers perceived links with other countries as extremely ineffective, $22(25.3 \%)$ as quite ineffective and $13(14.9 \%)$ as slightly ineffective. On the other hand $10(11.5 \%)$ Principals in 87 sampled centers perceived this model as extremely effective, $18(20.7 \%)$ as quite effective while $12(13.8 \%)$ perceived this model as slightly effective. This findings shows that majority of the Principals did not advocate for this model. This may be attributed to the fact that such arrangement requires intense logistical issues such as acquiring passports, sourcing for air fare and seeking for sponsors. Additional money may be required to meet some of these requirements therefore the need for parents to foot this bill. Shouldering extra financial costs has been an issue in the Kenya education system thus the mixed responses from the Principals. In addition a lot of learning time may be lost in the processes of travelling thus impacting on development of MI.

Further findings in Table 1 revealed that majority of the Principals were not of the view that there should be a directed and facilitated links with local, regional and international business. This is shown by $8(9.2 \%)$ Principals in 87 centers who perceived this model as extremely ineffective, 21 $(24.1 \%)$ as quite ineffective and $15(17.2 \%)$ as slightly ineffective. On the other hand $5(5.7 \%)$ Principals in 87 centers perceived this model as extremely 
effective, $12(13.8 \%)$ Principals as quite effective while 20 (23\%) Principals in 87 centers perceived this model as slightly effective. This may be attributed to lack of information on the kind of business in question. Though it's important to mention quite a number of Principals saw this model as a means for students to enhance their interpersonal abilities and linguistic abilities.

Further findings in Table 1 revealed that majority of the Principals were of the view that there should be a directed and facilitated links with corporate such as Safaricom, Yu, KCB and Coca cola just to mention but a few. This is shown by $18(20.7 \%)$ Principals in 87 sampled centers who perceived this model as extremely effective, $23(26.4 \%)$ as quite effective and $17(19.5 \%)$ as slightly effective. On the other hand 3 (3.4\%) Principals in 87 sampled centers perceived this model as extremely ineffective and $10(11.5 \%)$ as quite ineffective and $15(17.2 \%)$ as slightly ineffective. It's important to mention that such a model enhances students' leadership abilities and communicative abilities. Students may also gain skills in Mathematical and accounting skills associated with corporate entities mentioned.

Table 1 further revealed that $16(18.4 \%)$ Principals in 87 sampled centers perceived link with agencies such as Red Cross, KWS and others as being extremely effective in enhancing students varied abilities, 13 (14.9\%) as quite effective and $24(27.6 \%)$ as slightly effective. On the other hand 14 (16.1\%) Principals in 87 sampled centers perceived this model as extremely ineffective and $14(16.1 \%)$ as quite ineffective. This implies that students will be able to acquire skills related to intrapersonal an interpersonal intelligences by helping others. This is rarely achieved in a class room set up. In addition naturalistic intelligence in which students' have an appreciation of the natural world will be enhanced through appreciating the ecology around them.

Further findings in Table 1 revealed that majority of the Principals were of the view that there should be a directed and facilitated students representation in schools, churches boards and corporate. This is shown by 18 (20.7\%) Principals in 87 sampled centers who perceived this model as extremely effective, 16 (18.4\%) as quite effective and 22 (25.3\%) Principals in 87 sampled centers as slightly effective. On the other hand 19 (21.8\%) Principals perceived this model as quite ineffective and $8(9.2 \%)$ as slightly ineffective. It's important to mention that such a model enhances students' leadership abilities and communicative abilities thus the need to be enhanced.

Table 1 further revealed that $21(24.1 \%)$ Principals in 87 sampled centers perceived entrepreneurship programmes for students as being extremely effective in enhancing students varied abilities, 11(12.6\%) perceived as quite effective and 19 (21.8\%) Principals in 87 sampled centers as slightly effective. On the other hand 12 (13.8\%) Principals in 87 sampled centers perceived this model as quite ineffective and $16(18.4 \%)$ as being slightly effective. Entrepreneurship programmes do give students a platform 
upon which they can learn and acquire artistic and creative prowess in different intelligences such as painting, recording movies and songs, writing magazines, sculpturing and many others. In this way, the school helps students learn skills necessary to earn a living and promote sustainability in the community.

Further findings in Table 1 revealed that majority of the Principals were not of the view that there should be a directed and facilitated students job attachments and internship. This is shown by 16 (18.4\%) Principals in 87 sampled centers who perceived this model as extremely ineffective, 12 $(13.8 \%)$ as quite ineffective and $22(25.3 \%)$ as slightly ineffective. On the other hand $8(9.2 \%)$ Principals in 87 sampled centers perceived this model as extremely effective $13(14.9 \%)$ as quite effective and $9(10.3 \%)$ as slightly effective. It's important to mention that such a model enhances students' leadership abilities and communicative abilities thus the need to be enhanced.

Lastly the researcher looked at vocational work related programmes as a means of enhancing students $\mathrm{MI}$ and the results indicated that $19(21.8 \%)$ Principals in 87 sampled centers perceived this model as being extremely effective, $12(13.8 \%)$ as being quite effective and $23(26.4 \%)$ as being slightly effective. On the other hand $14(16.1 \%)$ Principals in 87 sampled centers perceived this model as being extremely ineffective, $6(6.9 \%)$ as being quite ineffective and $7(8.0 \%)$ as being slightly ineffective. This finding implies that students can be able to acquire hands on skills in practical jobs that involve agriculture and industry.

\subsection{Determining whether Alternative off School Business Management Model Enhances Multiple Intelligences among Students in Kenya.}

The third objective sought to find out whether alternative off school business management model enhances multiple intelligences among students in Kenya. The following hypothesis was hypothesized: Ho: There is no statistically significant relationship between the alternative off school business management model and enhancement of multiple intelligences among students in Kenya. Pearson's product correlation coefficient was applied to check linear relationship between alternative off school business management model and enhancement of multiple intelligences. The correlation is shown in the Table 2; 
Table 2: Correlations Analysis between the Dependent and Independent Variable

\begin{tabular}{|l|l|r|r|}
\hline \multicolumn{5}{|c|}{ Correlations } \\
\hline \multicolumn{2}{|c|}{} & $\begin{array}{c}\text { multiple } \\
\text { intelligence }\end{array}$ & $\begin{array}{c}\text { alternative off school } \\
\text { management model }\end{array}$ \\
\hline $\begin{array}{l}\text { Pearson } \\
\text { Correlation }\end{array}$ & multiple intelligence & 1.000 & .858 \\
\cline { 2 - 5 } & $\begin{array}{l}\text { alternative off school } \\
\text { management model }\end{array}$ & .858 & 1.000 \\
\hline \multirow{2}{*}{ Sig. (1-tailed) } & multiple intelligence & .000 \\
\cline { 2 - 5 } & $\begin{array}{l}\text { alternative off school } \\
\text { management model }\end{array}$ & .000 & 87 \\
\hline N & multiple intelligence & 87 & 87 \\
\cline { 2 - 5 } & $\begin{array}{l}\text { alternative off school } \\
\text { management model }\end{array}$ & 87 & .00 \\
\hline
\end{tabular}

** Correlation is significant at 0.001 level

Table 2 indicates that alternative off school business management model is positively and statistically significant $(\mathrm{r}=0.858, \mathrm{p}<0.001)$. This implies that alternative off school business management model is correlated to enhancement of multiple intelligences. Linear multiple regression analysis to determine the prediction of alternative off School business management Model on dependent variable (enhancement of multiple intelligence) was carried. The findings are presented in Table 3;

Table 3: Simple Linear Regression Analysis Model Summary of Alternative Off School Business Management Model for Enhancing Multiple Intelligences

Model summary

\begin{tabular}{|c|c|c|c|c|c|c|c|c|c|}
\hline \multirow[b]{2}{*}{ Model } & \multirow[b]{2}{*}{$\mathrm{R}$} & \multirow[b]{2}{*}{$\begin{array}{c}\mathrm{R} \\
\text { Square }\end{array}$} & \multirow[b]{2}{*}{$\begin{array}{l}\text { Adjusted } \\
\text { R Square }\end{array}$} & \multirow{2}{*}{$\begin{array}{l}\text { Std. Error } \\
\text { of the } \\
\text { Estimate }\end{array}$} & \multicolumn{5}{|c|}{ Change Statistics } \\
\hline & & & & & $\begin{array}{c}\text { R Square } \\
\text { Change }\end{array}$ & $\begin{array}{c}\mathrm{F} \\
\text { Change }\end{array}$ & df1 & df2 & $\begin{array}{l}\text { Sig. F } \\
\text { Change }\end{array}$ \\
\hline 1 & $.858^{\mathrm{a}}$ & .736 & .732 & 1.11768 & .736 & 236.488 & 1 & 85 & .000 \\
\hline
\end{tabular}

a. Predictors: (Constant), alternative off school business management model

As shown in Table 3 the $\mathrm{R}$ value which is a measure of correlation between the observed value and the predicted value of the dependent variable was 0.858 . Thus, 0.858 is the correlation coefficient between the levels of multiple intelligences in secondary school as reported by the respondents and the levels as would be predicted by the predictor variable. In the model $r^{2} \times 100=.736$ $\mathrm{x} 100 \%=73.6 \%$ indicating that $73.6 \%$ of the variance in the dependent variable is explained by the independent variable in the study. The R-square value indicates that this model succeeds in predicting up to $73.6 \%$ of the variable in enhancement of multiple intelligences in secondary school education. Table 4 presents the ANOVA output analysis. 
Table 4: Anova Output Analysis

\begin{tabular}{|l|l|r|r|r|r|r|}
\hline \multicolumn{7}{|l|}{ ANOVA $^{\text {a }}$} \\
\hline \multirow{2}{|l|}{ Model } & Sum of Squares & Df & Mean Square & F & Sig. \\
\hline \multirow{4}{*}{1} & Regression & 295.426 & 1 & 295.426 & 236.488 & $.000^{\mathrm{b}}$ \\
\cline { 2 - 7 } & Residual & 106.184 & 85 & 1.249 & & \\
\cline { 2 - 7 } & Total & 401.609 & 86 & & & \\
\hline
\end{tabular}

a. Dependent Variable: mutliple intelligence

b. Predictors: (Constant), alternative off school management model

Similarly, the ANOVA analysis is highly significant (0.000) indicating that the relationship between the independent variable and dependent variable is very strong. The table assesses the overall significance of the model and since $\mathrm{p}<0.05$, the simple linear regression model adopted in this study is relevant for the analysis. The ANOVA results of the simple linear regression analysis show that the regression equation is statistically appropriate to examine the relationship $(\mathrm{F}=236.488 ; \mathrm{df}=1 ; \mathrm{p}=0.05)$ at 0.05 level of significance. The model summary showed that the model can explain $73.6 \%$ variation in enhancing multiple intelligences that was occasioned by any changes in the alternative off school business management model. Table 4.17 presents the coefficient arising from the analysis.

Table 5: The Coefficients

\begin{tabular}{|c|c|c|c|c|c|c|}
\hline \multicolumn{7}{|c|}{ Coefficients $^{\mathrm{a}}$} \\
\hline \multirow{2}{*}{\multicolumn{2}{|c|}{ Model }} & \multicolumn{2}{|c|}{$\begin{array}{l}\text { Unstandardized } \\
\text { Coefficients }\end{array}$} & \multirow{2}{*}{$\begin{array}{c}\begin{array}{c}\text { Standardized } \\
\text { Coefficients }\end{array} \\
\text { Beta }\end{array}$} & \multirow[b]{2}{*}{$\mathrm{t}$} & \multirow[b]{2}{*}{ Sig. } \\
\hline & & B & Std. Error & & & \\
\hline & (Constant) & 1.027 & .220 & & 4.660 & .000 \\
\hline & $\begin{array}{l}\text { alternative off school } \\
\text { management model }\end{array}$ & .869 & .056 & .858 & 15.378 & .000 \\
\hline
\end{tabular}

The simple linear regression analysis was conducted so as to determine the relationship between Alternative off school business management model and enhancement of multiple intelligences. The equation $\mathbf{Y}=\boldsymbol{\alpha}+\boldsymbol{\beta} \mathbf{X}$ therefore becomes:

$$
\mathrm{Y}=1.027+0.869 \mathrm{X}
$$

Where $\mathrm{Y}$ is the dependent variable (Multiple intelligence), $\mathrm{X}$ is Alternative off School business management Model. According to the $1 \mathrm{i} \mathrm{n}$ e a $\mathrm{r}$ regression equation established, taking alternative off School business management model constant at zero, multiple intelligence will be 1.027. A unit increase in a lternative off School business management model will lead to a 0.869 increase of multiple intelligence.

\subsection{Conclusion}

The school management plays a key role in terms of directing coordinating, facilitating and supervising off school management models 
(practices) that are important in enhancing multiple intelligence among students. The study found that the off school business management model being managed in schools did not have any activity that enhanced MI from students. Most of the activities that were carried out in schools (that is the off school business) were geared towards academic excellence that focuses on a narrow scope of intelligences involving linguistic and logical intelligences leaving out other non academic intelligences such as musical, bodily, interpersonal, naturalistic, intrapersonal and spatial intelligences. It is significant to point that, many students don't function well in logical and linguistic intelligences being spearheaded in school thus a need to enhance spatial, musical, interpersonal, intrapersonal, naturalistic and bodily/kinesthetic intelligences that carries the bulk of students. This can be achieved if schools as the study has shown pursues alternative off School Business Management models such as; entrepreneurship programmes, working with other educational institutions, linking with corporate such as Safaricom, Yu, KCB and Coca cola, agencies such as Red Cross, KWS and others as perceived by majority of Principals. These activities may provide students with a platform upon which they can show case their artistic and creative prowess in different intelligences such as painting, recording movies and songs, writing magazines, sculpturing and many others.

\section{References:}

1.Boit, M., Njoki, A., \& Chang'ach, J. K. (2012). The influence of examinations on the stated curriculum goals. American International Journal of Contemporary Research, 2 (2), 179 -182.

2. Boonma, M., \& Phaiboonnugulkij, M. (2014). Why is an application of multiple intelligences theory important for language learning and teaching speaking ability? Advances in Language and Literary Sstudies, 5 (5) $162-168$.

3. Briggs, A., Coleman, M., \& Morrison, M. (2012). Research methods in education leadership and management. Thousand Oaks: Sage Publications.

4. Castro, M., Expósito-Casas, E., López-Martín, E., Lizasoain, L., Navarro-Asencio, E., \& Gaviria, J. L. (2015). Parental involvement on student academic achievement: A meta-analysis. Educational Research Review, 14, 33-46.

5. Cohen, L., Manion, L. \& Morrison, K. (2013) Research Methods in Education. London and New York: Routledge,

6. Creswell, J. W. (2013). "Steps in conducting a scholarly mixed methods study". DBER Speaker series. 48.http://digitalcommons.unl.edu/dberspeakers/48 
7. Johnson, R. B. (2014). Mixed methods research design and analysis with validity: A primer. Department of Professional Studies, University of South Alabama, USA.

8. Deschenes, S., Arbreton, A., Little, P., Herrera, C., Baldwin Grossman, J., Weiss, H., \& Lee, D. (2010). "Engaging older youth: program and city-level strategies to support sustained participation in out-of-school time." Harvard Family Research Project. http://www.hfrp.org/out-of-school-time/publicationsresources/engaging-older-youth-program-and-city-level-strategies-tosupport-sustained-participation-in-out-of-school-time.

9. Emerson, L., Fear. J., Fox, S., \& Sanders, E. (2012). Parental engagement in learning and schooling: Lessons from research. A report by the Australian Research Alliance for Children and Youth (ARACY) for the Family - School and Community Partnerships Bureau: Canberra.

10. Gardner, H. (2006). Multiple Intelligences. New York: Basic Books.

11. Marty McCall, M., Jiao, H., \& Harris, G. (2013). Construct validity and measurement invariance of computerized adaptive testing: Application to measures of academic progress (MAP) using confirmatory factor analysis. Shudong Wang Journal of Educational and Developmental Psychology, 3 (1), 88 100.

12. McEvoy, N. (2013). "One Size Fits All Learning Preferences: an Exploration of Rapid Authoring Tools," Irish Journal of Academic Practice, 2 (1).

13. Ombour, P. (2014). School Entrepreneurs. The Daily Nation, p. 14.

14. Onwuegbuzie, A. J., \& Collins, M. T. K (2007). A typology of mixed methods sampling designs in social science research. The Qualitative Report, 12, 281-316.

15. Phonkhao, N \& Ounjit, W (2012). Social structure and early childhood learning enhancement. Social and behavioral sciences 65 ( 2012 ) 225 $-231$

16. Sebba, J. (2007). An investigation of personalized learning approaches used by schools. Research Report. University of Sussex.

17. Sulim, G. (2012). Prediction of the correlation between the strategies of the teaching methods and the multiple intelligence of some graduate female students at Iman Mohammad Ibn Saud Islamic University. Social and Behavioural Sciences, 47, 1268 -1275.

18. UNDP, (2011). Sustainable development in Kenya: stock taking in the run up to Rio+ 20. Nairobi: UNDESA. 